\title{
Osteogenesis Imperfecta: Morphologic and Biochemical Studies of Connective Tissue
}

\author{
Fenwiak C. Riley ${ }^{[63]}$ and Jenifer Jowsey \\ Departments of Ophthalmology and Orthopedic Research, Mayo Clinic and Mayo Foundation, Rachester, Minnesota, USA \\ DAVID M. BROWN \\ Department of Pediatrics, University of Minnesota, Minneapolis, Minnescta, USA
}

\begin{abstract}
Extract
In iliac crest biopsies from 11 patients (ages from 4 to 22 years) with osteogenesis imperfecta, cortical thickness, osteoid width, and number of osteons were less than normal at all ages. Bone surface activity (formation and resorption), measured by quantitative microradiography, was lower than normal in younger patients; the normal pubertal decrease in surface activity was not evident in patients with osteogenesis imperfecta and, consequently, bone surface activity in the older patients was higher than in age-matched normal subjects. The ultrastructure of osteocytes, bone collagen, and scleral collagen did not differ from normal; corneal collagen fibers, however, were approximately half the diameter of normal. Total urinary hydroxyproline excretion, measured in 11 patients, was below normal in all except 2 infants (less than 12 months old). Serum parathyroid hormone levels, measured in nine patients, were normal. Long term treatment with sodium fluoride (two patients) and treatment with magnesium oxide (three patients) did not alter bone morphology or bone surface activity.
\end{abstract}

\section{Speculation}

The supposition that in osteogenesis imperfecta the connective tissue is characterized by an immature form of collagen was not substantiated by this study. The abnormal fibrillar pattern and paucity of collagen in various connective tissues suggest a qualitative defect, related to collagen maturation, as well as a quantitative deficit in the amount of collagen produced.

\section{Introduction}

Osteogenesis imperfecta is a congenital skeletal disorder characterized by fragility of the bones and frequent fractures. Because of the associated findings of blue sclera, deafness, dental abnormalities, weak ligaments, and paucity of dermal collagen, the disease has been considered to represent a generalized disorder of mesenchymal tissue $[16,18,37]$. The metabolic disorder responsible for the condition, however, remains an enigma; for this reason it has been difficult to develop a rational approach to treatment, other than surgical correction of skeletal deformities which result from the fractures.

Morphologic studies of bone by Robichon and Germain [44] revealed hyperosteocytosis, normal osteo- 
blasts with few osteoclasts, and a bony architecture which varied from an immature to a mature lamellar pattern, as well as increased intratrabecular resorption; these authors postulated that the disease is caused by increased bone resorption. Frost and coworkers, in a series of publications [25, 42, 57], reported normal and supranormal bone formation rates in osteogenesis imperfecta and suggested an impairment of centrifugally directed bone surface drifts which result from an abnormal cellular environment. Engfeldt $e t$ al. [17] observed that collagen bundles in compact bone from patients with osteogenesis imperfecta had an irregular arrangement resulting in a coarse fibrillar bone of immature type with little evidence of secondary bone formation; mineralization appeared more uniform than normal, but x-ray diffraction showed normal crystal patterns. Electron microscopic studies of bone from patients with osteogenesis imperfecta have demonstrated normal collagen and osteocytic ultrastructure in two instances $[15,34]$, but abnormal collagen in a third [21].

Histochemical studies by Spencer [50] implicated an abnormality of mucopolysaccharide in cartilage and bone which the author postulated might affect crystal nucleation. Biochemical analysis of mucopolysaccharides in osteogenesis imperfecta has shown decreased levels in bone [48] and increased levels in cartilage [8]. Although amino acid abnormalities have been reported in osteogenesis imperfecta $[10,53,54]$, Albright and Grunt [3] were unable to confirm such abnormalities and found normal calcium kinetics and balance studies of calcium, phosphorus, nitrogen, magnesium, and potassium.

Increased plasma levels of hypoprotein, which supposedly represents a collagen pool, have been demonstrated [32, 33], while total urinary hydroxyproline has been found to be increased [32], normal [30], or decreased [39]. Niemann [40] demonstrated an increase of aspartic and glutamic acids and a decrease of lysine in bone collagen. Bleckmann et al. [8] found normal proline and hydroxyproline content in bone with an increase in hydroxylysine; these authors postulated a deficiency in cross-linking of collagen. Investigations of cellular oxidative metabolism have suggested that osteogenesis imperfecta is a generalized metabolic disorder with a disturbance of high energy phosphate metabolism which results in abnormal pyrophosphate metabolism [22, 49].

As a result of the confusion regarding the basic abnormality in osteogenesis imperfecta, a variety of systemic treatments have been suggested for this disease, including ascorbic acid [59], sodium fluoride [2, 3, 31], and magnesium oxide [49]. Evaluation of the efficacy of treatment from these reports is difficult because the numbers of patients treated are small and the results are generally expressed in terms of a decrease in the number of fractures occurring in a relatively short period. In osteogenesis imperfecta, the incidence of fractures is notoriously sporadic, which makes this an unreliable criterion of response to therapy. In the largest series reported [3], fluoride therapy resulted in no significant metabolic change or alteration in fracture incidence.

The only report in which systemic therapy has been evaluated in respect to the effect on bone is that by Albright and Albright [4], who utilized serial rib biopsies and demonstrated decreased bone resorption after treatment with sodium fluoride.

The present study was undertaken to investigate collagen ultrastructure in bone and ocular tissues, to evaluate bone morphology and remodeling, and to study some biochemical features which relate to bone metabolism in osteogenesis imperfecta. In addition, we examined the possible effects of systemic therapy on some of these variables.

\section{Methods}

This study was based on 20 patients with osteogenesis imperfecta, aged from 1 month to 39 years (Table I). Half of the group were born with fractures or had fractures in the immediate perinatal period and appear to represent osteogenesis imperfecta congenita, while the remainder had fractures later in life and represent osteogenesis imperfecta tarda. The degree of skeletal involvement was based on the frequency of fractures and residual skeletal deformities. Twelve patients were judged to have severe involvement; only three of these were ambulatory and the rest were confined to bed or to a wheelchair. Four patients had moderate skeletal involvement and four had mild disease; all of these patients were ambulatory. Six patients had a family history of osteogenesis imperfecta, and the affected parents of two of the patients are included; in neither instance was there an antecedent history of osteogenesis imperfecta in the family. Blue sclerae and dental involvement were present in all but one patient who had mild skeletal disease. A significant hearing deficit, presumably due to otosclerosis, was found in seven patients.

The ocular tissues were obtained, at autopsy, from an 18-month-old girl with osteogenesis imperfecta who 
Tab!e I. Summary cf subjects in study ${ }^{1}$

\begin{tabular}{|c|c|c|c|c|c|c|c|c|c|c|c|c|c|c|c|}
\hline \multicolumn{2}{|c|}{ Age } & \multirow{3}{*}{ Sex } & \multirow{3}{*}{$\begin{array}{l}\text { Family } \\
\text { history }\end{array}$} & \multirow{3}{*}{$\begin{array}{c}\text { Degree of } \\
\text { involvement }\end{array}$} & \multicolumn{4}{|r|}{ Clinical signs } & \multirow{3}{*}{ Status } & \multicolumn{4}{|c|}{ Studies } & & \\
\hline \multirow{2}{*}{$\mathrm{mo}$} & \multirow{2}{*}{$\mathrm{yr}$} & & & & \multirow{2}{*}{$\begin{array}{l}\text { Blue } \\
\text { sclerá }\end{array}$} & \multirow{2}{*}{$\begin{array}{l}\text { Oto- } \\
\text { sclero- } \\
\text { sis }\end{array}$} & \multirow{2}{*}{ Teeth } & \multirow{2}{*}{ Fractures } & & \multicolumn{2}{|c|}{$\begin{array}{c}\text { Bone } \\
\text { histology }\end{array}$} & \multirow{2}{*}{$\begin{array}{l}\text { Urin- } \\
\text { ary } \\
\text { hy- } \\
\text { droxy- } \\
\text { pro- } \\
\text { line }\end{array}$} & \multirow{2}{*}{$\begin{array}{l}\mathrm{Ca} / \\
\mathrm{PTHI}\end{array}$} & \multicolumn{2}{|c|}{ Treatment } \\
\hline & & & & & & & & & & $\mathrm{QM}$ & ENI & & & $\mathrm{F}$ & $\mathrm{MgO}$ \\
\hline 1 & & $\mathrm{M}$ & - & Severe & + & & & Antenatal, multiple & $\mathrm{BR}$ & & & + & & & \\
\hline 10 & & $\mathrm{M}$ & - & Severc & + & & + & Antenatal, multiple & $\mathrm{BR}$ & & + & + & & & \\
\hline 12 & & $F$ & + & Severe & + & + & + & Antenatal, multiple & $\mathrm{BR}$ & & + & + & + & & \\
\hline 20 & & $\mathrm{M}$ & - & Moderate & + & & + & 3 Fractures in $18 \mathrm{mo}$ & $\mathrm{Amb}$ & & & + & & & \\
\hline & 4 & M & + & Severe & + & & + & Multiple; onset at $6 \mathrm{mo}$ & $\mathrm{Amb}$ & + & + & & & & + \\
\hline & 4 & $F$ & + & Sescre & + & & + & Multiple; onset at $6 \mathrm{mo}$ & $A m b$ & + & & + & & + & + \\
\hline & 4.5 & $\mathrm{~F}$ & + & Severe & + & + & + & Antenatal; multiple, lst yr; $1-2$ yr & WC. & & & + & & & \\
\hline & 6 & $M$ & - & Mild & + & & + & Initial at $1 \mathrm{yr} ; 1, \mathrm{yr}$ & Amb & + & & + & & & \\
\hline & 6 & $F$ & + & Severe & + & + & + & Antenatal, multiple & WC: & & + & + & + & & \\
\hline & 8 & $M$ & - & Moderate & + & & + & Initial in 1 st $\mathrm{yr} ; 1 / \mathrm{yr}$ & Amb & + & & & + & + & + \\
\hline & 10 & M & - & Mild & & & & Initial at 5 yt; sporadic & $A \mathrm{mb}$ & + & & & & & \\
\hline & 11 & F & - & Moderate: & + & & + & Initial in $1 \mathrm{st} y \mathrm{r}, 1 / \mathrm{y} \mathrm{r}$ & $A m b$ & + & + & + & + & & \\
\hline & 11 & $\mathrm{M}$ & - & Mild & + & & + & Initial at $18 \mathrm{mo} ; 1 / \mathrm{yr}$ & $\mathrm{Amb}$ & + & & & & & \\
\hline & 1.3 & $\mathbf{F}$ & - & Mild & + & & + & Initial at $2 \mathrm{yr} ; 1 / 2 \mathrm{yr}$ & Amb & + & & & + & & \\
\hline & 14 & $\mathrm{M}$ & - & Severe & + & + & + & Antenatal $; 1-2 / y \mathrm{r}$ in childhood & WC: & & + & + & & & \\
\hline & 18 & $\mathrm{M}$ & + & Severe & + & & + & Perinatal $; 1-2 / y r$ in childhrod & WC & + & & & & & \\
\hline & 18 & $M$ & - & Severe & + & & + & Antenatal; $1-2 / \mathrm{yr}$ in childhood & $\mathrm{Amb}$ & + & & & + & & \\
\hline & 22 & M & - & Severe & + & + & + & Antenatal; $1-2 / y r$ in childhood & WC & + & + & + & + & & \\
\hline & 30 & $\Gamma^{2}$ & - & Severe & + & + & + & Antenatal; multiple in childhood & WC & & & & + & & \\
\hline & 33 & $F^{3}$ & - & Moderate & + & + & + & Multiple in childhood & $\mathrm{Amb}$ & & & & + & & \\
\hline
\end{tabular}

I M : Male; F: female; BR: bedridden; WC: wheelchair; Amb: ambulatory; $Q M$ : quantitative microradiography; EM : electron microscopy; PTH : serum parathyroid hormone.

2 Mother of 12 -month-old girl

${ }^{3}$ Mother of 6-year-old girl.

died from injuries suffered in an automobile accident. She had experienced multiple fractures, the roentgenograms were typical of osteogenesis imperfecta, and the diagnosis was confirmed histologically at autopsy.

Bone biopsy specimens were taken from the iliac crest and long bones of 18 patients. Two of these patients had received sodium fluoride for a year or longer. Specimens of long bone which included or were taken adjacent to fracture sites reflected the activity of a healing fracture rather than osteogenesis imperfecta. Therefore, only those iliac crest specimens which showed no evidence of microfractures or previous fractures were utilized in the analysis; 11 specimens met these criteria. In three patients, biopsy specimens were taken before and again after more than 6 months of magnesium oxide administration.

\section{Quantitative Microradiography}

Bone specimens for microradiography were fixed in alcohol and embedded in methyl methacrylate; undecalcified sections were cut with a toothed metal saw [26]. Two sections of each specimen were evaluated by quantitative microradiography; this method [26, 27] provides a numerical evaluation of the amount of resorption and formation taking place in a piece of bone tissue. The mineralized section was stained with Para- gon stain and used for histologic study. Active surfaces of bone formation or resorption were identified on a microradiograph of a mineralized bone section. Bone resorption produces an uneven, crenated surface of high mineral density which correlates with the presenc? of osteoclasts. Areas of bone formation are of low mineral density with a smooth surface not bounded by a sclerotic line; this appearance has besn correlated with the presence of osteoblasts, with a border of osteoid tissue, and with a surface that accumulates tetracycline (tetracycline deposition has been shown to be associated with the calcification of collagen [38]).

In the present study, bone-forming surface was iclentified both microradiographically and histologically in the stained section. The lengths of surfaces undergoing resorption or formation were measured on an enlarged photomicrograph and expressed quantitatively as a percentage of the total surface in the section. These values, therefore, refer to the amount of surface involved in the two aspects of bone turnover, bone resorption and bone formation. The values differ in different sites within the same skeleton but bear a relatively constant ratio to each other. The surface measurements reflect changes in the longitudinal rate of formation and resorption but not the radial rate of these processes. To equate surface measurements with 
radial rates of bone formation and resorption, it is nece sary to make the reasonable but unproved assumption that the radial rate of bone deposition or destruction per unit length of active surface is relatively constant. By use of tetracycline labeling, it has been shown that the appositional rate of bone formation is about $1 \mu \mathrm{m} / 24 \mathrm{hr}$ in a group of patients with a variety of medical cliseases [19]. The theoretical justification for the technique has been reviewed [27, 43].

Normal iliac crest bone was obtained from individuals dying acutely, generally as the result of automobile or fire acciclents. The control group consisted of 48 persons from $0-24$ years of age.

\section{Measurement of Osleoid}

All measurements were made on $100-\mu$ m thick undecalcified sections cut from the bone biopsy specimen embedded in methyl methacrylate. When examined microscopically at a magnification of X 100, osteoid appeared as a longitudinally streaked, semitranslucent, glossy material lying on a bone surface; osteocytes were clearly visible, having been incorporated into slit-like lacunae in the osteoid. Thin layers of fibrous material, only a few microns thick, were not measured. When these criteria were observed strictly, osteoid was distinguishable from artifacts such as areas of separation of the soft tissue from the bone surface, thin layers of fibrous tissue and marrow elements, and tissue edges cut tangentially. Osteoid borders varied in configuration but generally were crescent-shaped. Paired measurements were made on each border midway between the center-point of maximal thickness and the tapered lateral edge, with care taken to avoid obvious distortions. Each section was examined until 10 paired observations were obtained or until the specimen was completely scanned. If a section did not have 10 osteoid borders, additional sections were prepared and scanned until this number could be obtained. If sufficient measurements could not be made from a total of six sections, the case was discarcled from the study. Osteoid tissue on periosteal surfaces was not measured. A mean value was obtained for each patient.

\section{Serum Parathyroid Hormone Levels}

Circulating parathyroid hormone was measured in serum samples from nine patients with osteogenesis imperfecta, ranging in age from 1 to 33 years. Five were patients from whom bone biopsy specimens were obtained. The measurements were made by Dr. C. D. Arnaud [60] by a radioimmunoassay previously de- scribed [5]. Serum calcium was measured in these same patients by atomic absorption spectrophotometry. Serum parathyroid hormone data were analyzed in relationship to age- and sex-matched normal inclivicluals by Dr. Sara B. Arnaud [6].

\section{Total Urinary Hydroxyproline}

Patients with osteogenesis imperfecta and a group of age-matched control subjects were placed on gelatinfree diets before collection of 24-hr urine samples. Bone biopsy specimens were obtained from 4 of these 11 patients. Total urinary hydroxyproline was determined by the modification described by Kivirikko et al. [29].

\section{Electron Microscopy}

For electron microscopy, fresh bone specimens were placed into $4 \%$ glutaraldehyde buffered to $\mathrm{pH} 7.2$ with $0.05 \mathrm{M}$ sodium cacodylate for $3 \mathrm{hr}$. After fixation the tissue was transferred to fresh cacodylate buffer. The specimens were then decalcified at $4^{\circ}$ in $0.05 \mathrm{M}$ ethylenediaminetetraacetate, $\mathrm{pH}$ 7.2. After decalcification, the tissue was rinsed in cacodylate buffer and then postfixed in $1 \%$ osmic acid. The tissue was dehydrated and embedded in a resin consisting of Epon 812 and Nadic methyl anhydride, with DMP-30 added as a catalyst. Sections were cut with a Porter-Blum MT2 microtome and stained with uranyl acetate and lead citrate. Thick sections $(0.5 \mu \mathrm{m})$ were stained with azure II.

Specimens of ocular tissue, obtained at autopsy from an 18-month-old girl with osteogenesis imperfecta and from two children of similar age with no ocular disease, were initially fixed in $10 \%$ neutral buffered formalin. Tissue blocks of cornea and sclera for electron microscopy were placed in $4 \%$ glutaraldehycle buffered with sodium cacodylate and then processed as described above with the exception of the decalcification step. The remainder of the globes were embedded in paraffin for sectioning, and stained with hematoxylin and eosin, toluidine blue, Alcian blue ( $\mathrm{pH} 0.4$ and $2.5)$, reticulin, elastic-van Gieson, and periodic acidSchiff.

\section{Results}

When complete manifestations of osteogenesis imperfecta are present, the clinical diagnosis is not difficult. If, however, the skeletal involvement is not accompanied by other findings, such as blue sclerae, osteogene- 

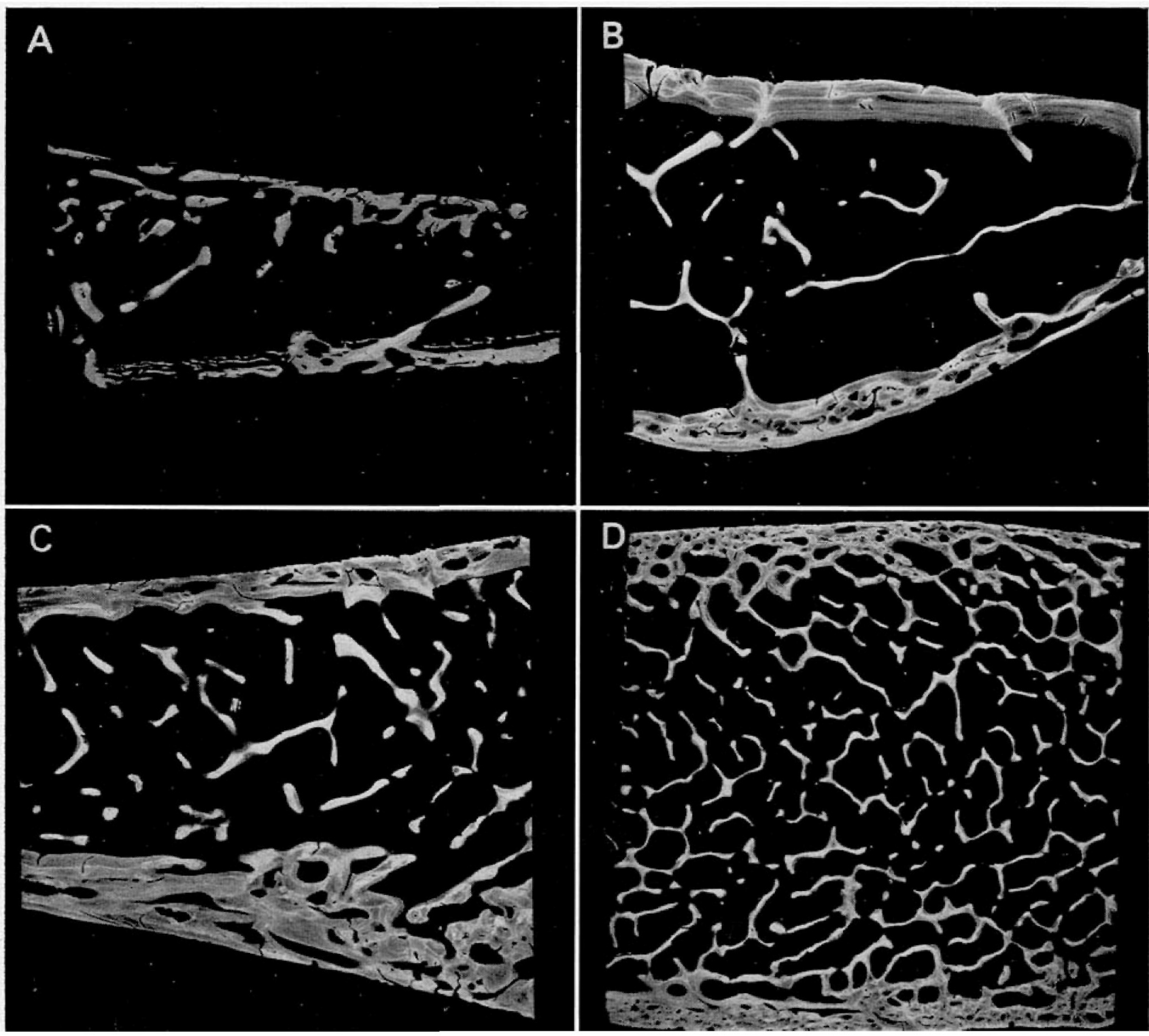

Fig. 1. Microradiographs of sections from iliac crest. $A$ and $B:$ With osteogenesis imperfecta. $A: 4$-year-old boy (X 7$) ; B: 20$-year-old man (X 7). $C$ and $D:$ Normal subjects. C: 4-year-old boy $(\times 7) ; D: 20$-year-old man (X 5$)$.

sis imperfecta may be misdiagnosed as osteoporosis; in textbooks it is described as a variety of osteoporosis [20,37]. Roentgenographically, osteogenesis imperfecta usually can be distinguished from idiopathic juvenile osteoporosis by the generalized thinness of bone cortex (in idiopathic juvenile osteoporosis, the cortex is of normal thickness). Compared with those from agematched control subjects, bone biopsies from young patients with osteogenesis imperfecta are characterized by a thin cortex, few trabeculae, and a homogeneous mineral density with little evidence of bone remodel- ing or Haversian systems (Fig. I). In older patients with osteogenesis imperfecta, although these features persist, there appears to be more extensive bone remodeling.

\section{Bone Remodeling in Osteogenesis Imperfecta}

Cortical thickness, osteoid width, and the number of osteons per section remained less than normal at all ages for which biopsy specimens were available (Fig. 2). Bone formation and resorption surfaces were below normal in the younger patients but these levels ap- 

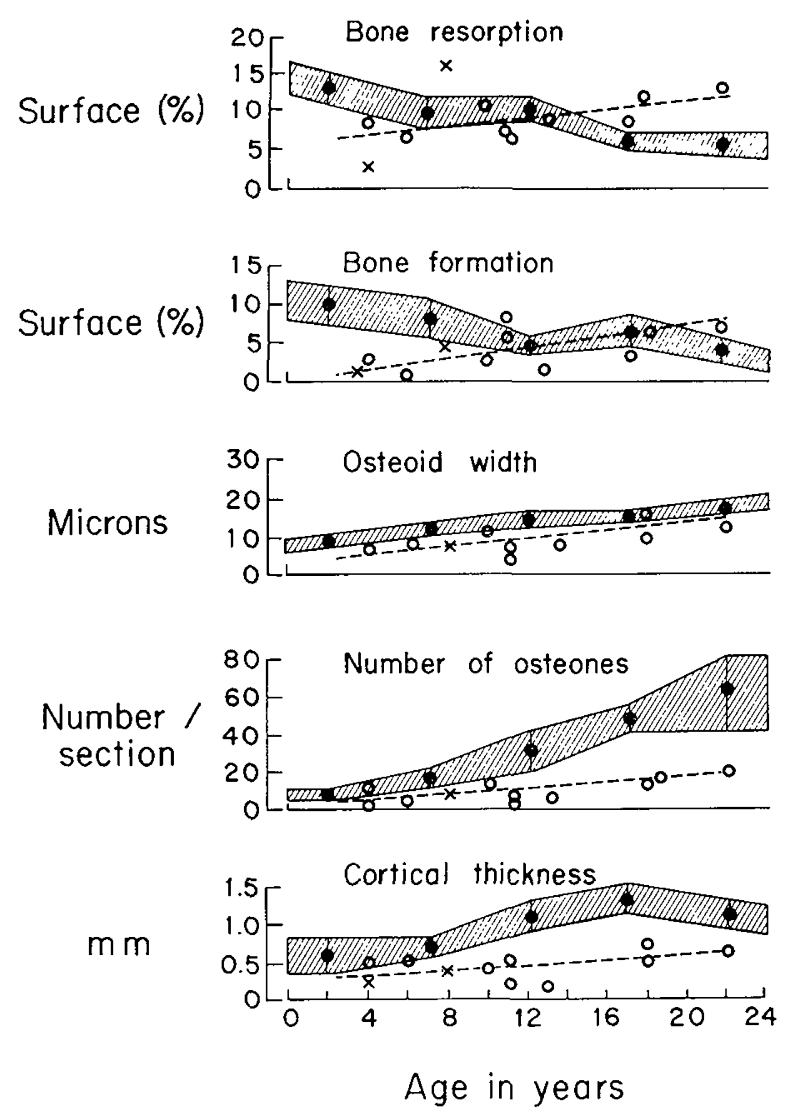

Fig. 2. Quantitative morphologic data in osteogenesis imperfecta ( $O, x$ : patients treated with sodium fluoride) patients compared with normal subjects ( $\bullet$, hatched area is range of normal).

peared to increase slightly with increasing age. Consequently, when the normal values decrease at puberty, a "cross-over" occurred and bone formation and resorption in patients with osteogenesis imperfecta were then higher than normal.

Two patients with osteogenesis imperfecta who had been treated with sodium fluoride ( $1 \mathrm{mg} / \mathrm{kg} / 24 \mathrm{hr}$ ) for more than 2 years before biopsy showed no difference from untreated patients in bone morphology or in the variables measured, with the exception of bone resorption, which was higher than normal in one patient; this may have been due to a secondary stimulation of parathyroid hormone as a result of fluoride treatment. Significantly, despite the high dose and long term administration of fluoride, there was no morphologic evidence of fluorosis or of any effect on mineralization of bone, which is expected and has been the invariable finding in osteoporotic patients treated with this level of fluoride [28].

In three patients, bone biopsies before and after treatment with magnesium oxide $(15 \mathrm{mg} / \mathrm{kg} / 24 \mathrm{hr})$ for more than 6 months demonstrated no alteration of bone morphology or in bone resorption and formation as a result of treatment (Table II).

In stained sections of bone, the surfaces of specimens from patients with osteogenesis imperfecta were frequently covered by a layer of spindle-shaped cells which appeared to be connective tissue cells. In some areas this layer was as thick as $300 \mu \mathrm{m}$. These cells were not present in control bone tissue (Fig. 3). This connective tissue layer resembled the changes seen in primary and secondary hyperparathyroidism, although the bone morphology and remodeling did not appear similar.

The serum parathyroid hormone levels for the nine patients in whom it was measured all fell within the normal range (Table III), and serum calcium levels were near mean normal [6]. It is interesting to note that, in the two youngest patients, the parathyroid hormone levels were at the lower end of the normal range for age- and sex-matched control subjects whereas in the remainder of the patients the serum parathyroid hormone levels were in the upper half of the normal range for age- and sex-matched control subjects.

\section{Urinary Hydroxyproline}

Control levels of urinary hydroxyproline fell within the midrange of normal values published by Prockop and Kivirikko [41]. Total urinary hydroxyproline in the patients with osteogenesis imperfecta was below the normal range at all ages, with the exception of two who were less than 12 months of age (Table IV).

Table II. Effect of magnesium oxide treatment (15 mg/ $\mathrm{kg} / 24$ $\mathrm{hr}$ ) on bone resorption and formation in osteogenesis imperfecta

\begin{tabular}{lccc}
\hline & \multicolumn{3}{c}{ Patients } \\
\cline { 2 - 4 } & 1 & 2 & 3 \\
\hline Age, yr & 41 & 41 & 82 \\
Duration of treatment, mo & 7 & 7 & 8 \\
Bone resorption, \% & & & \\
Before treatment & 8.7 & 2.7 & 15.4 \\
After treatment & 9.7 & 5.3 & 12.4 \\
Bone formation, \% & & & \\
Before treatment & 3.1 & 1.8 & 4.6 \\
After treatment & 6.7 & 2.7 & 2.3 \\
\hline
\end{tabular}

\footnotetext{
${ }^{1}$ Female.
}

${ }^{2}$ Male. 


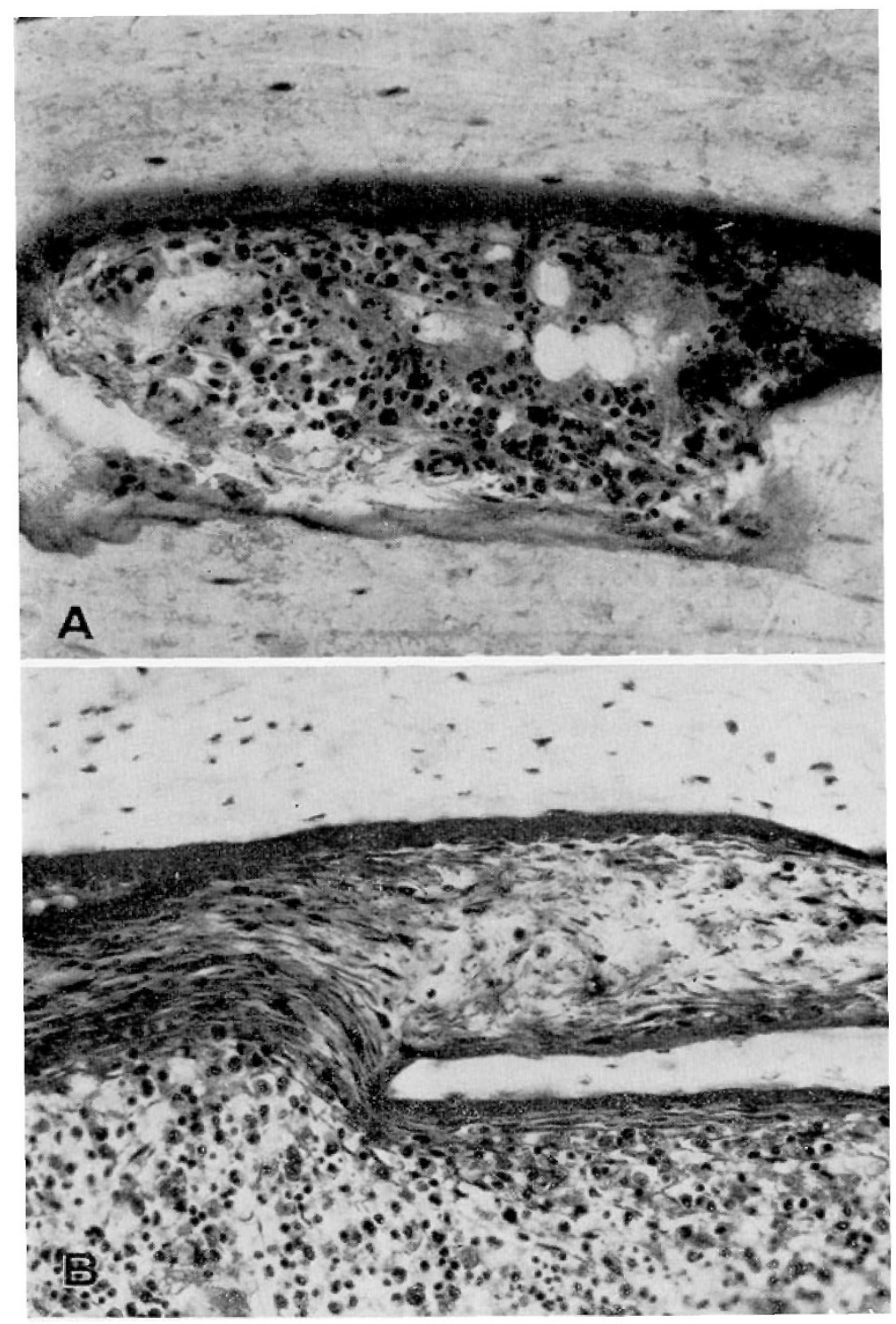

Fig. 3. Histologic preparations of iliac crest bone (Paragon stain; $\times$ 200). A: Normal; B: ostecgenesis impcrfecta, showing bone surface covered by band of connective tissue.

\section{Ultrastructure Studies in Osteogenesis Imperfecta}

The ultrastructure of osteocytes in decalcified sections of bone from patients with osteogenesis imperfecta appeared comparable with that in control specimens. Periodicity of collagen fibers and fiber diameters were normal; adjacent to osteocyte lacunae the fibers were approximately $400-450 \AA$ in diameter while in the matrix away from lacunae the diameter was approximately $1,000 \AA$. In areas with incomplete decalcification, bone mineral showed what appeared to be an appropriate relation to collagen fibers.

Corneal and scleral thicknesses of the eyes from an autopsy case of osteogenesis imperfecta did not differ significantly from normal. Likewise, no consistent difference in staining characteristics was noted with toluidine blue, Alcian blue ( $\mathrm{pH} 0.4$ and 2.5), reticulin, elastic-van Gieson, or periodic acid-Schiff. The major difference from normal observed in sclera from the case of osteogenesis imperfecta was in the organization of the collagenous bundles. In normal sclera, the collagen was arranged in interlacing lamellae which demonstrated a fairly regular size, whereas, in osteogenesis imperfecta, there was little evidence of lamellar formation and the collagen showed a disorganized fibrillar 
Table III. Serum parathyroid hormone levels in nine patients with osteogenesis imperfecta ${ }^{1}$

\begin{tabular}{|c|c|c|c|}
\hline \multirow{2}{*}{ Age, $\mathrm{yr}$} & \multirow{2}{*}{$\begin{array}{l}\text { Serum Ca, } \\
\mathrm{mg} / 100 \mathrm{ml}\end{array}$} & \multicolumn{2}{|r|}{$\mathrm{PTH}, \mu \mathrm{leq} / \mathrm{ml}$} \\
\hline & & Patient & Normal $[5,6]$ mean, range \\
\hline $2 / 3$ & 10.3 & 13 & $22(\mathrm{ND}-56)$ \\
\hline 6 & 9.9 & 12 & 16 (ND-34) \\
\hline 8 & 9.3 & 24 & $16(\mathrm{ND}-34)$ \\
\hline 11 & 9.7 & 22 & $16(\mathrm{ND}-34)$ \\
\hline 13 & 9.8 & 41 & $20(\mathrm{ND}-44)$ \\
\hline 18 & 10.2 & 19 & $20(\mathrm{ND}-44)$ \\
\hline 22 & 9.2 & 27 & ${ }^{2}(\mathrm{ND}-38)$ \\
\hline 30 & 9.1 & 30 & ${ }^{2}(\mathrm{ND}-38)$ \\
\hline 33 & 9.2 & 25 & ${ }^{2}(\mathrm{ND}-38)$ \\
\hline
\end{tabular}

${ }^{1}$ PTH: Serum parathyroid hormone; ND: not detectable.

${ }^{2}$ Inversely proportional to serum calcium.

Table IV. Total urinary hydroxyproline in osteogenesis imperfecta

\begin{tabular}{|c|c|c|c|}
\hline \multicolumn{2}{|c|}{ Age } & \multicolumn{2}{|c|}{ Urinary hydroxyproline, $\mathrm{mg} / \mathrm{m}^{2} / 24 \mathrm{hr}$} \\
\hline mo & $\mathrm{yr}$ & $\begin{array}{l}\text { Osteogenesis } \\
\text { imperfecta }\end{array}$ & $\underset{[41]}{\text { Normal range }}{ }^{1}$ \\
\hline 1 & & 127.4 & $40-191$ \\
\hline \multirow[t]{10}{*}{8} & & 125.0 & \\
\hline & 1.8 & 21.7 & $37-95$ \\
\hline & 1.8 & 37.1 & \\
\hline & 4 & 23.2 & \\
\hline & 4.5 & 29.7 & \\
\hline & 6 & 24.5 & \\
\hline & 6 & 24.5 & \\
\hline & 11 & 18.0 & $40-113$ \\
\hline & 14 & 39.1 & \\
\hline & 22 & 7.2 & $9-24$ \\
\hline
\end{tabular}

I The normal range represents 2 sD above and below the mean for the age. appearance (Fig. 4). Similarly, the corneal lamellae appeared to be finer than normal. The scleral ultrastructure appeared to be similar to normal in periodicity and diameter and in the distribution of elastic fibers. In the cornea, however, the collagen fibers were of smaller diameter than normal and showed a greater separation between fibers (Fig. 5); the periodicity was normal.

\section{Discussion}

In attempting to explain osteogenesis imperfecta as a connective tissue disorder, consideration must be given to the possibility of an abnormality involving the major constituents of connective tissues-namely, collagen, proteoglycans, and glycosaminoglycans. The ultrastructure of collagen in bone and sclera in osteogenesis imperfecta appears to be normal in periodicity and fiber diameter. Although the electron microscopic appearance of collagen fibers may not describe completely the biochemical and biophysical character of

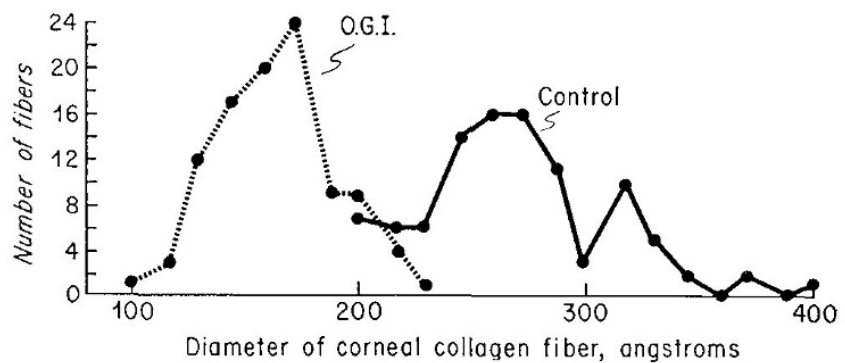

Fig. 5. Distributions of diameters of corneal collagen fibers in normal subject (-) and case of osteogenesis imperfecta $(O . G . I).(---\bullet)$; both subjects were 18-month-old girls.
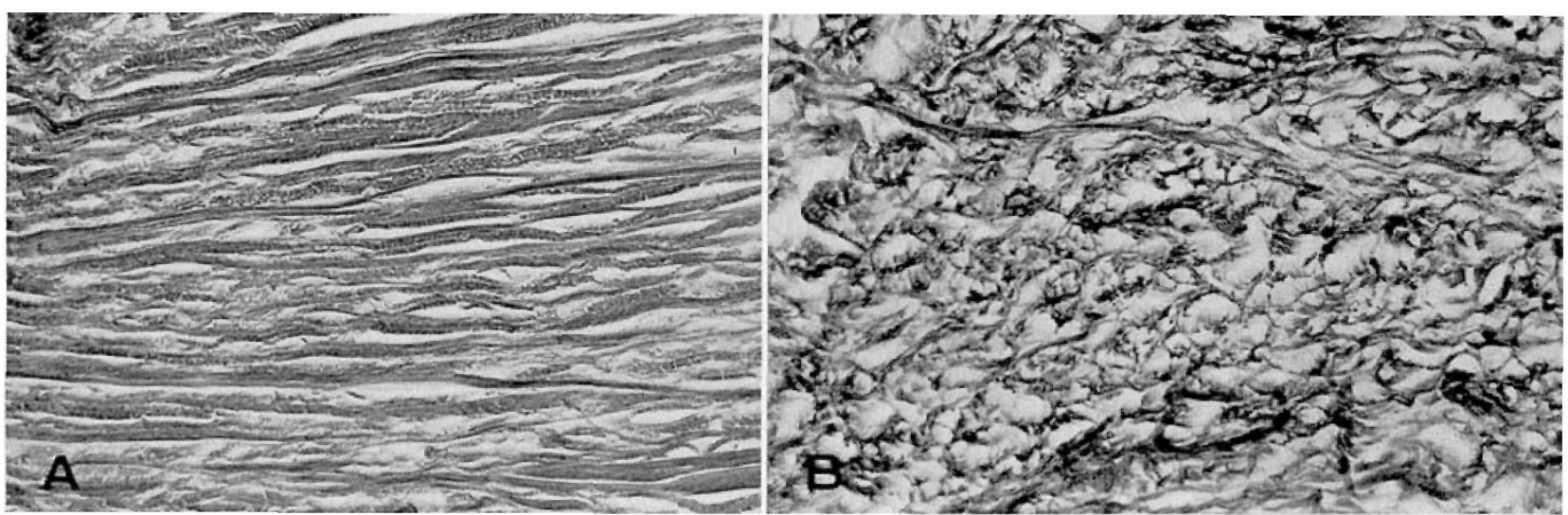

Fig. 4. Scleral collagen from posterior portion of globe (18-month-old girls) (elastic-van Gieson; $\times$ 285). A: Normal; B: osteogenesis imperfecta, showing fine fibrillar structure with absence of lamellar pattern seen normally. 
the fibers as they exist in the natural state, it gives reasonable evidence that the basic aggregation of tropocollagen molecules to form collagen fibers has occurred in a manner which cannot be differentiated from normal. The morphologic abnormality of collagen in osteogenesis imperfecta appears to involve a higher level of connective tissue organization-aggregation of individual collagen fibers to form the collagen bundles which produce the lamellar pattern characteristic of normal collagenous tissues. Abnormal fibrillar patterns in osteogenesis imperfecta have been found in hone [17], skin [18], and stapes [9], as well as in the sclera in the present study.

Maturation of collagen involves stabilization by the formation of intermolecular and intramolecular crosslinkages of tropocollagen [14, 47], and interactions with proteoglycans and glycosaminoglycans [24, 55, 58]. Defects in cross-linkage formation, such as occur in lathyrism, result in a higher proportion of soluble collagen [7]. The reports of altered lysine [40] and hydroxylysine [8] contents of bone collagen in osteogenesis imperfecta may reflect abnormal cross-linkage formation in collagen, which would not necessarily be apparent in the ultrastructure.

The exception to apparently normal collagen fiber diameters occurs in the cornea, where the fiber diameter is approximately half of normal. Cornea is an unusual collagenous tissue which has a high mucopolysaccharide content (approximately 4-4.5\%, dry weight) compared with that of sclera $(1 \%)$ [36], skin $(0.1-0.5 \%)$, clentin $(0.4 \%)$, or bone $(0.24 \%)$ [56]. The normal periodicity, however, suggests that the abnormal fiber diameter in this tissue may be due to a failure of fiber growth or maturation.

Fibroblast tissue cultures derived from skin of patients with osteogenesis imperfecta are currently being studied [11]. Preliminary results demonstrate the formation of a greater proportion of soluble collagen, which would be consistent with defective cross-linkage formation.

Argyrophilia of connective tissue has been described as a histochemical characteristic of osteogenesis imperlecta $[18,45,51]$ and has been interpreted as demonstrating reticulin or immature collagen. Electron microscopic observations in this and previous studies [9, 34] have not verified this supposition because the collagen has a normal diameter rather than the 400-500 $\AA$ characteristic of reticulin. Irving and Tomlin [23] have shown that the argyrophilia of reticulin is an interface phenomenon due to silver precipitation in mucopolysaccharides associated with collagen fibrils and that mature collagen can be made argyrophilic by treatment with hyaluronic acid. The argyrophilia in osteogenesis imperfecta suggests an alteration of the normal relation of collagen and mucopolysaccharides rather than an immature collagen. A defect of crosslinkage formation would be expected to result in an abnormality in the usual maturation of collagen fibers and, clue to a failure in the condensation of collagen fibers, might explain the argyrophilia observed in collagenous tissues of this disease.

This hypothesis, however, does not necessarily explain the decreased amounts of collagen in skin [52] and the paucity of bone. In younger patients with osteogenesis imperfecta, we observed a thin cortex, few trabeculae, subnormal amounts of osteoid, and a uniform mineral density. The bone surface activity was clecreased when compared with age-matched normal children; however, because the volume of bone is dramatically decreased in this disorder, the remodeling rate or turnover of tissue will be reciprocally increased. With increasing age, cortical thickness and osteoid width tended to increase but remained subnormal. The major change occurring as age increases seems to be an increase in bone surface activity. Although the percentages of bone formation and resorption tend to reach levels higher than those in agematched control subjects, these levels are comparable with the control values found in younger age groups. The result is bone which, although it retains many of the stigmata of osteogenesis imperfecta, loses its uniform mineral density and acquires some of the appearance of normal remodeled bone. This would suggest some retardation or incompetence in the ability of the bone cells to respond to normal stimuli for bone remodeling. Fibroblast tissue culture studies [11, 35] have demonstrated that cells from patients with osteogenesis imperfecta produce less collagen than fibroblasts from normal persons, which suggests that the connective tissue abnormality is quantitative as well as qualitative.

The significance of the connective tissue cells observed on bone surfaces remains to be explained. Although this resembled the changes seen in hyperparathyroidism, serum levels of parathyroid hormone in a group of patients with osteogenesis imperfecta fell within the normal range.

It has been suggested $[44,57]$ that the skeletal changes in osteogenesis imperfecta result from increased bone resorption. Our observations of bone sur- 
face activity indicate a lower-than-normal resorption level in younger patients with this disease, which appears to be reflected in the low parathyroid hormone and urinary hydroxyproline values. In spite of the low surface activity, because of the remarkably small amount of bone that characterizes this disorder, bone turnover will be clearly above normal. At later ages, formation and resorption are higher than normal and parathyroid hormone levels tend to be in the upper end of the normal range, and the low urinary hydroxyproline levels probably are related to the subnormal collagenous mass of these patients. The number of patients, however, is too small to allow any definite conclusions regarding the parathyroid hormone data.

Because the basic abnormality responsible for osteogenesis imperfecta remains unknown, any attempt at systemic treatment remains arbitrary. Long term, high dose fluoride treatment did not significantly alter bone morphology in two of the patients in this study. This in itself is intriguing because a comparable dosage in adults results in fluorosis [28]. The lack of any similar changes in these two children again suggests an inability of the bone cells to respond to stimuli which normally result in increased remodeling.

Reported abnormalities of pyrophosphate metabolism [49], abnormal leukocyte oxidative metabolism [22], and alterations of metabolic rates with increased serum thyroxine levels [13] have been interpreted as evidence of a generalized derangement of cellular oxidative metabolism in osteogenesis imperfecta. After puberty, metabolic rates in the patients studied were found to normalize [13]. Magnesium oxide, which was found to reverse the pyrophosphate alterations, has been proposed [49] as a form of treatment for osteogenesis imperfecta. Previous work [1] has shown that, in hyperthyroidism, both bone formation and bone resorption are increased. If the reported hypermetabolism has an effect on bone in osteogensis imperfecta, an increare of formation and resorption would be expected to occur in younger patients with normalization at pu berty. Our findings demonstrate an opposite trend, however, with initially low levels of formation and resorption which increase above normal at puberty. Treatment with magnesium oxide for varying periods produced no alteration of bone surface activity in three patients with osteogenesis imperfecta. Until the significance of the reported metabolic alterations has been more clearly defined, the justification for magnesium oxide treatment is open to question; subsequent investigations have been unable to corroborate the reported leukocyte [12] and pyrophosphate [46] abnormalities in osteogenesis imperfecta.

\section{Summary}

Cortical thickness, osteoid width, and number of osteons were less than normal at all ages in iliac crest biopsies from 11 patients (aged from 4 to 22 years) with osteogenesis imperfecta. Quantitative microradiography demonstrated that bone surface activity (formation and resorption) was lower than normal in younger patients, and the normal pubertal decrease in surface activity was not evident in patients with osteogenesis imperfecta. The ultrastructure of osteocytes, bone collagen, and scleral collagen did not differ from normal; the diameter of corneal collagen fibers was approximately half the diameter of normal. Total urinary hydroxyproline excretion (11 patients) was below the normal range in all except two infants, whereas serum parathyroid hormone levels (nine patients) were within the normal range. Treatment with sodium fluoricle (two patients) and magnesium oxide (three patients) did not alter bone morphology or bone surface activity.

\section{References and Notes}

1. Adans, P. H., Jowsey, J., Kelly, P. J., Riggs, B. L., Kinney, $V$. R., AND JONES, J. D.: Effects of hyperthyroidism on bone and mincral metabolism in man. Quart. J. Med., 36: 1 $(1967)$.

2. Afschlimane, M. I., Grunt, J. A., and Grigler, J. F., Jr.: Effects of sodium fluoride on the clinical course and metabolic balance of an infant with osteogenesis imperfecta congenita. Metabolism, 15: 905 (1966).

3. Albright, J. A., And Grunt, J. A.: Studies of patients with osteogenesis imperfecta. J. Bone Joint Surg. A Amer. Vol., 53: 1415 (1971).

4. Albright, J. P., and Albright, J. A.: Osteogenesis imperfecta: Serial rib biopsies in three patients treated with low doses of fluoride (Abstract). J. Bone Joint Surg. A Amer. Vol., 53: 801 (1971).

5. Arnaud, C. D., Tsao, H. S., and Littledike, T.: Radioimmunoassay of human parathyroid hormone in serum. J. Clin. Invest., 50: 21 (1971).

6. Arnaud, S. B., Goldsmith, R. S., Stickler, G. B., McCali., J. T., And Arnaud, C. D.: Serum parathyroid hormone and blood minerals: Interrelationships in normal children. Pcdiat. Res., 7: 5 (1973).

7. Balley, A. J., Peach, C. M., ANd Fowler, L. J.: The biosynthesis of intermolecular crosslinks in collagen. In: E. A. Balazs: Chemistry and Molecular Biology of the Intcrcellular Matrix, Vol. 1, p. 385. (Academic Press, New York, 1970.)

8. Bleckmann, H., Kresse, H., Wollensak, J., and Buddecke, R.: Glykosaminoglykan- und Kollagenanalysen bei Osteogenesis imperfecta. Z. Kinderheilk., 110: 74 (1971). 
9. Bretlau, P., Balslev Jørgensen, M., and Johansen, H.: Osteogenesis imperfecta: Light and electron microscopic studies of the stapes. Acta Oto-laryngol., 69: 172 (1970).

10. Brigham, M. P., and Tourtellotte, C. D.: Amino acid changes in blood and urine in osteogenesis imperfecta (Abstract). Fed. Proc., 21: 167 (1962).

11. Brown, D. M.: Unpublished data.

12. Brown, D. M., Park, B. H., and Holmes, B. M.: Metabolic studies of leukocytes of patients with osteogenesis imperfecta. J. Pediat., 80: 221 (1972).

13. Cropp, G. J. A., ANd Myers, D. N.: Physiological evidence of hypermetabolism in osteogenesis imperfecta. Pediatrics, 49: 375 (1972).

14. Deshmukr, K., and Nimn, M. E.: Chemical changes associated with aging of collagen in vivo and in vitro. Biochem. J., 112: 397 (1969).

15. Doty, S. B., AND Matthew's, R. S.: Electron microscopic and histochemical investigation of osteogenesis imperfecta tarda. Clin. Orthop. Related Res., 80: 191 (1971).

16. Eddowes, A.: Dark sclerotics and fragilitas ossium. Brit. Med. J., 2: $222(1900)$.

17. EngFeldt, B., Engström, A., And Zetterström, R.: Biophysical studics of the bone tissue in osteogenesis imperfecta. J. Bone Joint Surg. B Brit. Vol., 36: 654 (1954).

18. Fol.tis, R. H., JR.: Osteogenesis imperfecta congenita: A connective tissue diathesis. J. Pediat., 41: 713 (1952).

19. Frost, H. M.: Measurement of human bone formation by means of tetracycline labeling. Can. J. Biochem., 41: 31 (1963).

20. Gardner, D. L.: Pathology of the Connective Tissue Diseases. (The Williams \& Wilkins Co., Baltimore, 1965).

21. Haebara, H., Yamasaki, Y., and Kyogonv, M.: An autopsy case of osteogenesis imperfecta congenita: Histochemical and elcctron microscopical studies. Acta Pathol. Jap., 19: 377 (1969).

22. Humbert, J. R., Solomons, C. C., And Ott, J. E.: Increased oxidative metabolism by leukocytes of patients with osteogenesis imperfecta and of their relatives. J. Pediat., $78: 648$ (1971).

23. Irving, E. A., and Tomlin, S. G.: Collagen, reticulum and their argyrophilic properties. Proc. Roy. Soc. Ser. B Biol. Sci., 142: 113 (1954).

24. JACKson, D. S., ANd Bentley, J. P.: Collagen-glycosaminoglycan interactions. In: B. S. Gould: Treatise on Collagen, Vol. 2, Part A, p. 189. (Acadcmic Press, New York, 1968).

25. Jett, S., Ramser, J. R., Frost, H. M., and Villanueva, A. R.: Bone turnover and osteogenesis imperfecta. Arch. Pathol., 81: 112 (1966).

26. JowSF.Y, J.: Quantitative microradiography: A new approach in the evaluation of metabolic bone disease (Editorial). Amer. J. Med., t0: 485 (1966).

27. Jowsey, J., Kelly, P. J., Riggs, B. L., Bianco, A. J., JR., Scholz, D. A., And Gershon-Cohen, J.: Quantitative microradiographic studies of normal and osteoporotic bone. J. Bone Joint Surg. A Amer. Vol., 47: 785 (1965).

28. Jowsey, J., SChenk, R. K., ANd Reutrer, F. W.: Some results of the effect of fluoride on bone tissue in osteoporosis. J. Clin. Endocrinol. Metabol., 28: 869 (1968).

29. Kivikikko, K. I., Laitinen, O., and Prockop, D. J.: Modifi- cations of a specific assay for hydroxyproline in urine. Anal. Biochem., 19: 249 (1967).

30. Kocher, P.: Étude de l'hydroxyprolinurie dans les ostéopathies. Pathol. Biol., 14: 1020 (1966).

31. Kuzemko, J. A.: Osteogenesis imperfecta tarda treated with sodium fluoride. Arch. Dis. Childhood, 45: 581 (1970).

32. LANGNESS, U., AND BEHNKE, H.: Collagen metabolites in plasma and urine in osteogenesis imperfecta. Metabolism, 20: $456(1971)$.

33. LeRoy, E. C., AND SJofrdsma, A.: Clinical significance of a hydroxyproline-containing protein in human plasma. $\mathrm{J}$ Clin. Invest., 4 : 914 (1965).

34. Lrrtle, K.: Osteogencsis imperfecta (Abstract). J. Bone Joint Surg. B Brit. Vol., 45: 221 (1963).

35. Martin, G. R., Layman, D. L., Narayanan, A. S., Nigra, T. P., AND Sregel, R. C.: Collagen synthesis by cultured human fibroblasts. Israel J. Med. Sci., 7: 455 (1971).

36. Maurice, D. M.: The cornea and sclera. In: H. Davson: The Eye, Ed. 2, Vol. 1, p. 489. (Academic Press, New York, 1969).

37. McKusick, V. A.: Heritable Disorders of Connective Tissue, Ed. 3. (C. V. Mosby, St. Louis, 1966).

38. Milch, R. A., Rall, D. P., aNd Tobie, J. E.: Bonc localization of the tetracyclines. J. Nat. Cancer Inst., 19: 87 (1957).

39. Mrtona, C., Smith, T. E., Davidson, J. D., Udenfriend, S., DaCosta, F. M., ANd Sjocrdsina, A.: Improvements in methods for measuring hydroxyproline: Application to human urine. J. Lab. Clin. Med., 53: 970 (1959).

40. Nieman, K. M. W.: Amino acid composition of bone collagen in osteogenesis imperfecta (Abstract). J. Bone Joint Surg. A Amer. Vol., 51: 804 (1969).

41. Prockop, D. J., And Kivirikko, K. I.: Relationship of hydroxyproline excretion in urine to collagen metabolism. Ann. Intern. Med., 66: 1243 (1967)

42. Ramiser, J. R., Villanueva, A. R., Pirok, D., and Frost, H. M.: Tetracycline-based measurement of bone dynamics in 3 women with osteogenesis imperfecta. Clin. Orthop. Related Res., 49: 151 (1966).

43. Rasmussen, H., and Tennenhouse, A.: Thyrocalcitonin, osteoporosis and osteolysis. Amer. J. Med., f3: 711 (1967).

44. Robichon, J., ANd Germain, J. P.: Pathogenesis of osteogenesis imperfecta. Can. Med. Ass. J., 99: 975 (1968).

45. Ruedemann, A. D., JR.: Ostcogenesis imperfecta congenita and bluc sclerotics: A clinicopathologic study. Arch. Oph. thalmol., 49: 6 (1953).

46. Russell, R. G. G., Bisaz, S., Donath, A., Morgan, D. B., AND ILeISCH, H.: Inorganic pyrophosphate in plasma in normal persons and in patients with hypophosphatasia, osteogenesis imperfecta, and other disorders of bone. J. Clin. Invest., 50 : $961(197 \mathrm{I})$

47. Salazar, M. E., Paz, M. A., Salomone, J., and González CADAvid, N. F.: Variations in some physicochemical properties of collagen with age. Proc. Soc. Exp. Biol. Med., 131: 970 (1969).

48. Sol.herm, K.: Osteogencsis imperfecta: Microradiographic and biochemical studies with special reference to the mucopolysaccharides (glycosaminoglycans). J. Oslo City Hosp., 19: 193 (1969).

49. Solomons, C. C., And Styner, J.: Osteogenesis imperfecta: Effect of magnesium administration on pyrophosphate metabolism. Calcified Tissue Res., 3: 318 (1969). 
50. Spencer, A. T.: A histochemical study of long bones in osteogenesis imperfecta congenita. J. Pathol., 83: 423 (1962).

51. Stadil, P.: Histopathology of the corium in osteogenesis imperfecta. Dan. Med. Bull., S: 131 (1961).

52. Stevenson, C. J., Botroms, E., And Shuster, S.: Skin collagen in osteogenesis imperfecta. Lancet, $i: 860\langle 1970\rangle$.

53. Sumater, G. K.: Oral proline tolerance in osteogenesis imperfecta. Science, 13t: 1527 (1961).

54. Summer, G. K., aNd Patron, W. C.: Intravenous proline tolerance in osteogenesis imperfecta. Metabolism, 17: 46 (1968).

55. Toole, B. P.: Solubility of collagen fibrils formed in vitro in the presence of sulphated acid mucopolysaccharide-protein (Letter to the Editor). Nature, 222: 872 (1969).

56. Veis, A., Spector, A. R., and Carmichael, D. J.: The organization and polymerization of bone and dentin collagens. Clin. Orthop. Related Res., 66: 188 (1969).

57. Villanueva, A. R., ANd Frost, H. M.: Bone formation in human osteogenesis imperfecta, measured by tetracycline bone labeling. Acta Orthop. Scand., 41: 531 (1970).

58. WASTESON, $\AA$., AND ÖBRINK, B.: Demonstration of an interaction between collagen and chondroitin sulphate. Biochim. Biophys. Acta, 170: 201 (1968).

59. Winterfeldt, E. A., EYring, E. J., ANd Vivian, V. M.: Ascorbic-acid treatment for osteogenesis imperfecta (Letter to the Editor). Lancet, $i: 1347$ (1970).

60. Mayo Clinic, Rochester, Minn.

61. Dr. D. M. Brown is a Research Career Development Awardee of the National Institute of Child Health and Human Development.

62. This research was supported by grants from the National Institutes of Health (AM-8658) and the Minnesota Arthritis Foundation.

63. Requests for reprints should be addressed to: F. C. Riley, M.D., Mayo Clinic, Rochester, Minn. 5590l (USA).

64. Accepted for publication April 18, 1973. 